\title{
Primary lymphoma of the liver: clinical and pathological features of 10 patients
}

\author{
P P Anthony, P Sarsfield, T Clarke
}

\begin{abstract}
Nine out of 10 patients with primary lymphoma of the liver presented in a manner that did not suggest a tumour. The initial diagnoses were chronic active hepatitis in three cases and "granulomatous cholangitis", inflammatory pseudotumour, and anaplastic carcinoma in one case each. Moreover, extensive haemorrhagic necrosis in three cases initially suggested the Budd-Chiari syndrome. All the tumours were diffuse non-Hodgkin's lymphomas like the $\mathbf{5 0}$ cases reported previously, but they differed from most of these in that nine were of $T$ cell phenotype. Five were pleomorphic small $T$ cell, two $T$ zone, and two $T$ lymphoblastic lymphomas: only one was centrocytic and of $B$ cell lineage. This report extends the range of clinical manifestations (diffuse hepatomegaly without a tumour), histological appearances (resemblance to chronic inflammatory or vascular liver diseases) and phenotype (of $T$ cell lineage) of primary lymphoma of the liver: these features seemed to be related in this series.
\end{abstract}

Recognition is important as prognosis remains favourable in appropriately treated cases. Although the appearances of the liver biopsy specimens may be difficult to interpret, the destructiveness of the infiltrate is an important clue to the diagnosis.

A lymphomatous infiltrate seen in a liver biopsy specimen has long been regarded as evidence of stage IV disease, the prognosis for which is poor. ${ }^{1}$ Such an infiltrate may, however, represent a primary lymphoma of the liver itself in which case the outlook is similar to that of other organ based lymphomas. $^{2}$ Recent experience indicates that these tumours are not rare.

Primary lymphomas of the liver recorded up to 1980 were usually single case reports of tumours found at necropsy and were not always fully documented. Over the past decade, however, some 50 new cases have been reported, 35 as series ranging from two to 10 patients, ${ }^{3-9}$ and an additional 15 as single cases, the latter mainly concerned with treatment, a specific complication, or an association suggesting pathogenesis. ${ }^{10-24}$ A recent review of 31 cases showed that the disease occurs over a wide age range, more commonly in men and presents as a mass in the liver. ${ }^{2}$ Most have been described as non-Hodgkin's lymphoma of poor prognostic subtype and, when this has been evaluated, of $B$ cell phenotype. A minority, however, occurred as diffuse infiltrates or were of $\mathrm{T}$ cell phenotype. ${ }^{5717}$

Personal experience over the past decade (PPA) has indicated that the diagnosis should be borne in mind in any case of an enlarged liver associated with an unusual cellular infiltrate, and that a tumour-like presentation is only one manifestation of the disease. Interpretation of the histopathological appearances in a needle biopsy specimen may be difficult and the diagnosis is then likely to be missed. These cases have been reinvestigated in terms of morphology and phenotype, and a full follow up was obtained. The findings are presented in the context of earlier reports.

\section{Methods}

Thirteen cases of primary lymphoma were encountered between 1980 and 1989, nine of which had been referred from elsewhere. Full follow up information could not be obtained in three referred cases and these were excluded from the study; the rest form the basis of this report.

Cases were accepted as being primary when the tumour was confined to the liver on presentation, but involvement of portal nodes was probably present in three patients and that of spleen in one. The initial referring diagnoses were "chronic active hepatitis" in three cases, "granulomatous cholangitis" (either sclerosing or primary biliary) in one, "inflammatory pseudotumour" in one and "anaplastic carcinoma" in one. The possibility of Budd-Chiari syndrome, due to extensive haemorrhagic necrosis, was raised in three cases.

\section{CLINICAL DETAILS}

The main clinical features, findings, and outcomes are summarised in table 1. Seven patients were male and three female, with an age range of 31 to 85 years (mean 57.9). The main symptoms were right upper quadrant or epigastric discomfort, or pain (seven cases). The liver was enlarged in nine patients and a discrete mass was palpable in one. B symptoms (fever, night sweats, weight loss) had been experienced by eight patients. Four patients were jaundiced on presentation. Six patients were anaemic (range of haemoglobin 8.5 to $10.6 \mathrm{~g} / 1$ ), one had neutropenia (white 
Table 1 Main clinical details of 10 patients with primary hepatic lymphoma

\begin{tabular}{|c|c|c|c|c|c|c|}
\hline Cases & Age & $/ \operatorname{sex}$ & Symptoms and signs & Tumour & Treatment & Outcome \\
\hline 1 & 60 & $\mathbf{F}$ & $\begin{array}{l}\text { Fever, weight loss, abdominal pain; } \\
\text { hepatomegaly }\end{array}$ & Diffuse & Multiagent chemotherapy & $\begin{array}{l}\text { Died of disease at two years } \\
\text { three months }\end{array}$ \\
\hline 2 & 53 & $\mathbf{M}$ & $\begin{array}{l}\text { Night sweats, weight loss, abdominal pain; } \\
\text { jaundice, hepatomegaly }\end{array}$ & Diffuse & $\begin{array}{l}\text { Prednisolone, later multiagent } \\
\text { chemotherapy }\end{array}$ & $\begin{array}{l}\text { Died of disease at one year } \\
\text { three months }\end{array}$ \\
\hline $\begin{array}{l}3 \\
4\end{array}$ & $\begin{array}{l}76 \\
61\end{array}$ & $\begin{array}{l}M \\
M\end{array}$ & $\begin{array}{l}\text { Abdominal pain; jaundice, hepatomegaly } \\
\text { Coeliac disease for four years; fever, weight } \\
\text { loss; hepatomegaly }\end{array}$ & $\begin{array}{l}\text { Diffuse } \\
\text { Diffuse }\end{array}$ & $\begin{array}{l}\text { Prednisolone and chlorambucil } \\
\text { Prednisolone, antibiotics }\end{array}$ & $\begin{array}{l}\text { Alive and well at three years } \\
\text { Died of disease at one year six } \\
\text { months }\end{array}$ \\
\hline 5 & 45 & $\mathbf{M}$ & Abdominal pain; hepatomegaly & Multinodular & Multiagent chemotherapy & Died of disease at six months \\
\hline 6 & 82 & F & $\begin{array}{l}\text { Congestive cardiac failure; weight loss; } \\
\text { jaundice, hepatomegaly }\end{array}$ & Diffuse & Prednisolone & $\begin{array}{l}\text { Died of myocardial infarction } \\
\text { at one week }\end{array}$ \\
\hline 7 & 46 & $\mathbf{M}$ & $\begin{array}{l}\text { Alcoholism; fever, weight loss, abdominal } \\
\text { pain; jaundice, hepatomegaly, ascites }\end{array}$ & Diffuse & Antibiotics & $\begin{array}{l}\text { Died of liver failure (? alcohol } \\
\text { ? tumour) at three weeks }\end{array}$ \\
\hline 8 & 85 & $\mathbf{F}$ & Weight loss; hepatomegaly & Diffuse & None & $\begin{array}{l}\text { Died of bronchopneumonia on } \\
\text { admission }\end{array}$ \\
\hline 9 & 41 & $\mathbf{M}$ & $\begin{array}{l}\text { Night sweats, abdominal pain; } \\
\text { hepatomegaly }\end{array}$ & Diffuse & Multiagent chemotherapy & Alive and well at six years \\
\hline 10 & 31 & $\mathbf{M}$ & $\begin{array}{l}\text { Weight loss, abdominal pain; mass in } \\
\text { epigastrium }\end{array}$ & $\begin{array}{l}20 \times 20 \mathrm{~cm} \\
\text { mass in left } \\
\text { lobe }\end{array}$ & Hemihepatectomy & $\begin{array}{l}\text { Died of postoperative } \\
\text { complications }\end{array}$ \\
\hline
\end{tabular}

cell count $3.1 \times 10^{9} / 1$, and one had an increased erythrocyte sedimentation rate (111 $\mathrm{mm}$ first hour). Variably raised serum alkaline phosphatase and aminotransferase activities were the most constantly recorded laboratory abnormalities.

Bone marrow aspirates, done in eight cases, showed no evidence of lymphoma. Chest $x$ ray pictures were normal in nine patients, as were barium meals and follow through in four and skeletal survey in three. Macroscopic descriptions of tumour-that is, diffuse, multinodular, or solitary - are based on a combination of imaging methods, laparoscopy or laparotomy, and findings at necropsy.

Only two patients (cases 3 and 9) were alive and free of disease at three and six years. Case 1 showed a good initial response to cyclophosphamide alone and was later treated more aggressively for two relapses, also successfully, but died of disease at two years and three months. In cases 2 and 4 the diagnosis of lymphoma was resisted by the physician: the former was thought to have chronic active hepatitis and the latter, a known coeliac, intestinal lymphoma. Despite delay in treatment these patients survived with gross liver disease for one year three months and one year six months, respectively. Case 5 never responded and died at six months. Cases 6, 7, and 8 presented with severe associated diseases: myocardial infarction, advanced chronic alcoholism, and chest infection from which they died soon after admission. Case 10, the youngest in the series, died of liver necrosis due to thrombosis of the right hepatic artery after hemihepatectomy which was complicated by sepsis and disseminated intravascular coagulation.

\section{HISTOPATHOLOGY AND}

\section{IMMUNOCYTOCHEMISTRY}

The histological material consisted of formalin fixed, paraffin wax embedded tissue from needle biopsy specimens (nine in all and multiple in three) wedge biopsy specimens taken at laparotomy $(n=4)$, a resection specimen $(n=1)$, and necropsies $(n=5)$. These were reviewed and the best pre-treatment sample was stained with haematoxylin and eosin, Gordon and Sweet's reticulin, and periodic acid Schiff with and without diastase for general morphology.

Immunocytochemistry was initially carried out using a panel of antisera against leucocyte common antigen (LCA) cytokeratins (AE1, AE3, and CAM 5.2), carcinoembryonic antigen (CEA), human milk fat globule antigen (HMFG), S100 protein, vimentin and neurone specific enolase (NSE). All tumour infiltrates were positive for LCA and negative for all the other markers. Reinvestigation for the purposes of this study entailed phenotyping by a panel of antibodies recommended for use on formalin fixed, paraffin wax embedded material. ${ }^{25-27}$ These included MB2, MT1 (Eurodiagnostics), L26, UCHLI, Ki-1 (BerH2) and immunoglobulin light chains (Dako). The streptavidin-biotin technique was used for all antisera at dilutions and with controls recommended by the manufacturers.

\section{Results}

Table 2 shows the microscopic patterns of liver pathology, the diagnoses in terms of the Kiel classification, and the main immunocytochemical findings. Results of the latter are expressed semiquantitatively. All tumours were negative for immunoglobulin light chains and the $\mathrm{Ki}-1$ antigen.

The morphological patterns of liver pathology were variable. In cases $2,3,4,6$, and 7 diffuse portal tract infiltrates were seen with erosion of the limiting plate and "spillover" into the sinusoids of the surrounding parenchyma (fig 1). This appearance had given rise to an initial diagnosis of chronic active hepatitis in cases 2,3 , and 4 which was reinforced by the reticulin pattern (fig 2). On close examination, however, the infiltrate was clearly destructive, with pronounced lytic necrosis of a peripheral zone of hepatocytes which was particularly noticeable on staining with periodic acid Schiff (fig 3). The predominant cell type in cases 2,4 , and 7 was a small lymphocyte with irregular, twisted, hyperchromatic nucleus (fig 4) which stained for $T$ cell markers. Cases 8 and 9 showed extensive liver disease, with destruction of 
Table 2 Pattern of liver disease, Kiel classification subtype, and main immunocytochemical findings in hepatic lymphoma

\begin{tabular}{|c|c|c|c|c|c|c|c|}
\hline \multirow[b]{2}{*}{ Case No } & \multirow[b]{2}{*}{ Microscopic pattern } & \multirow[b]{2}{*}{ Kiel classification subtype } & \multicolumn{5}{|c|}{ Monoclonal antibody } \\
\hline & & & $L C A$ & $M B 2$ & $L 26$ & $M T 1$ & UCHL1 \\
\hline $\begin{array}{l}1 \\
2\end{array}$ & $\begin{array}{l}\text { Nodular portal tract infiltrates } \\
\text { Destructive sinusoidal and portal tract infiltrates with } \\
\text { "lytic" edges, extensive haemorrhages }\end{array}$ & $\begin{array}{l}\text { Centrocytic } \\
\text { Pleomorphic small cell }\end{array}$ & $\begin{array}{l}+++ \\
++\end{array}$ & $\begin{array}{l}++ \\
\pm\end{array}$ & $\begin{array}{l}+++ \\
\pm\end{array}$ & \pm & $\overline{+}++$ \\
\hline $\begin{array}{l}3 \\
4\end{array}$ & $\begin{array}{l}\text { Destructive portal tract infiltrates } \\
\text { Destructive sinusoidal and portal tract infiltrates, } \\
\text { extensive haemorrhages }\end{array}$ & $\begin{array}{l}\text { T zone } \\
\text { Pleomorphic small cell }\end{array}$ & $\begin{array}{l}+++ \\
+++\end{array}$ & \pm & \pm & $\begin{array}{l}++ \\
+\end{array}$ & $\begin{array}{l}+++ \\
++\end{array}$ \\
\hline $\begin{array}{l}5 \\
6 \\
7\end{array}$ & $\begin{array}{l}\text { Massive replacement of large areas of liver } \\
\text { Destructive portal tract infiltrates } \\
\text { Destructive sinusoidal and portal tract infiltrates, } \\
\text { extensive haemorrhages }\end{array}$ & $\begin{array}{l}\text { Lymphoblastic } \\
\text { T zone } \\
\text { Pleomorphic small cell }\end{array}$ & $\begin{array}{l}+++ \\
+++ \\
+++\end{array}$ & $\begin{array}{l}- \\
\overline{ \pm}\end{array}$ & $\begin{array}{l} \pm \\
\pm\end{array}$ & $\begin{array}{l}++ \\
++ \\
++\end{array}$ & $\begin{array}{l}++ \\
+++ \\
++\end{array}$ \\
\hline $\begin{array}{r}8 \\
9 \\
10\end{array}$ & $\begin{array}{l}\text { Extensive replacement of large areas of liver } \\
\text { Extensive replacement of large areas of liver } \\
\text { Solitary mass }\end{array}$ & $\begin{array}{l}\text { Pleomorphic small cell } \\
\text { Pleomorphic small cell } \\
\text { Lymphoblastic }\end{array}$ & $\begin{array}{l}+++ \\
++ \\
++\end{array}$ & $\begin{array}{l}- \\
\overline{ \pm}\end{array}$ & $\begin{array}{l}- \\
\overline{+}\end{array}$ & $\begin{array}{l}+ \\
+ \\
+\end{array}$ & $\begin{array}{l}++ \\
+ \\
++\end{array}$ \\
\hline
\end{tabular}

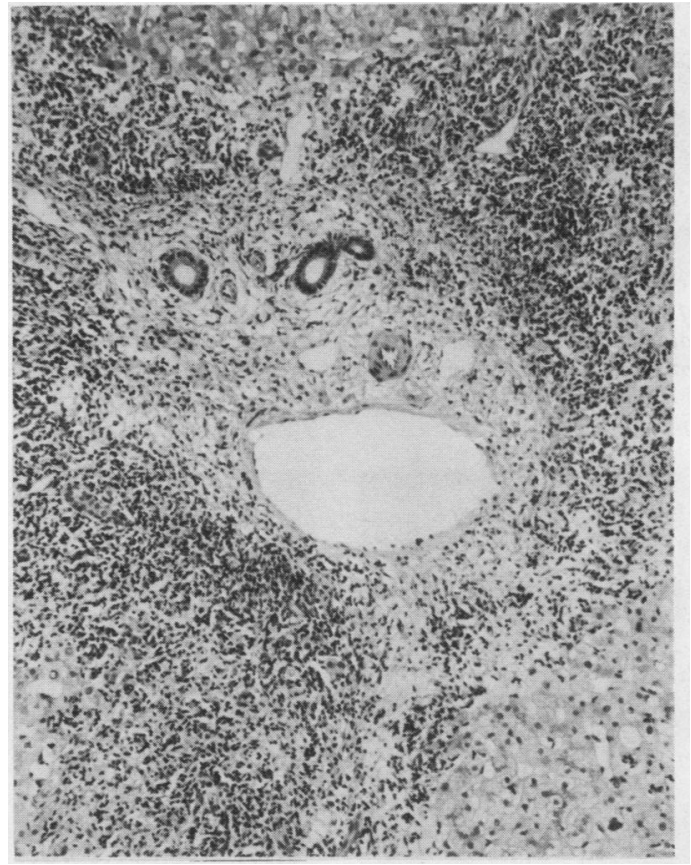

Figure 1 Case 2: a destructive mononuclear cell infiltrate at edges of portal tract with disruption of parenchyma (haematoxylin and eosin).

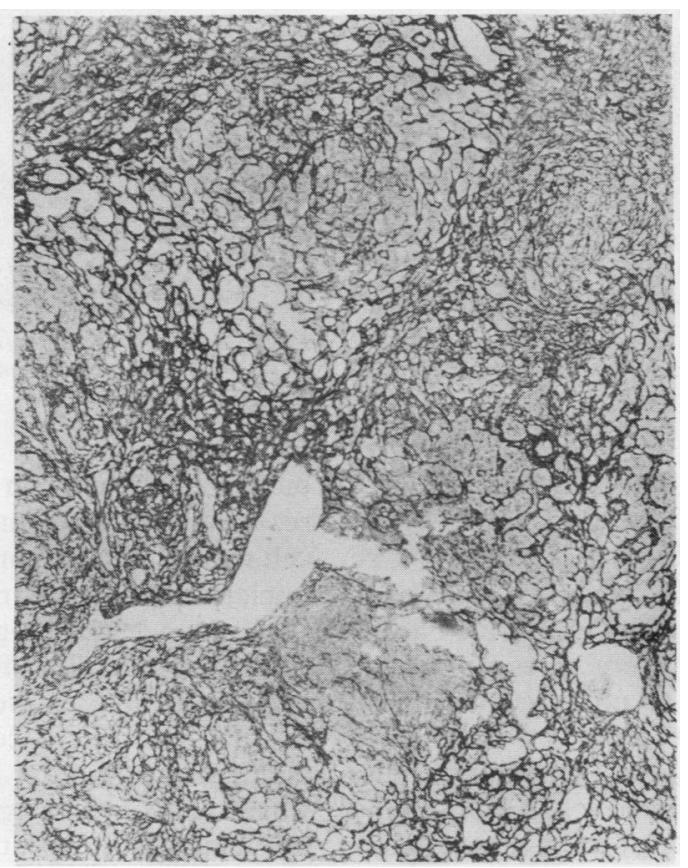

Figure 2 Case 2: another area of the same biopsy specimen stained for reticulin. Note pattern resembling chronic active hepatitis (Gordon $\mathcal{E}$ 'Sweet's reticulin).

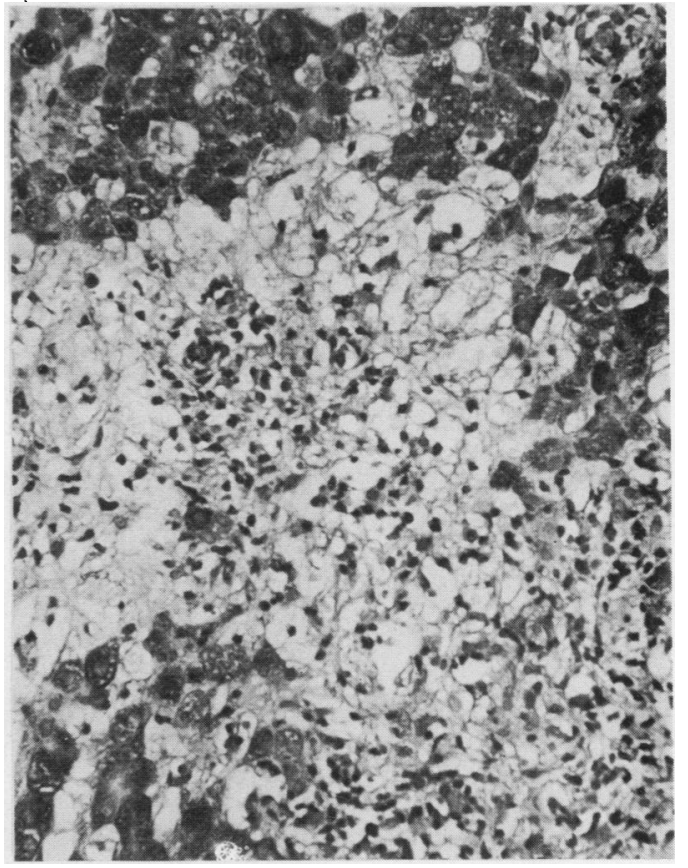

Figure 3 Case 3: peculiar lytic necrosis (pale) of hepatocytes between normal parenchyma (dark) and advancing tumour margin (periodic acid Schiff).

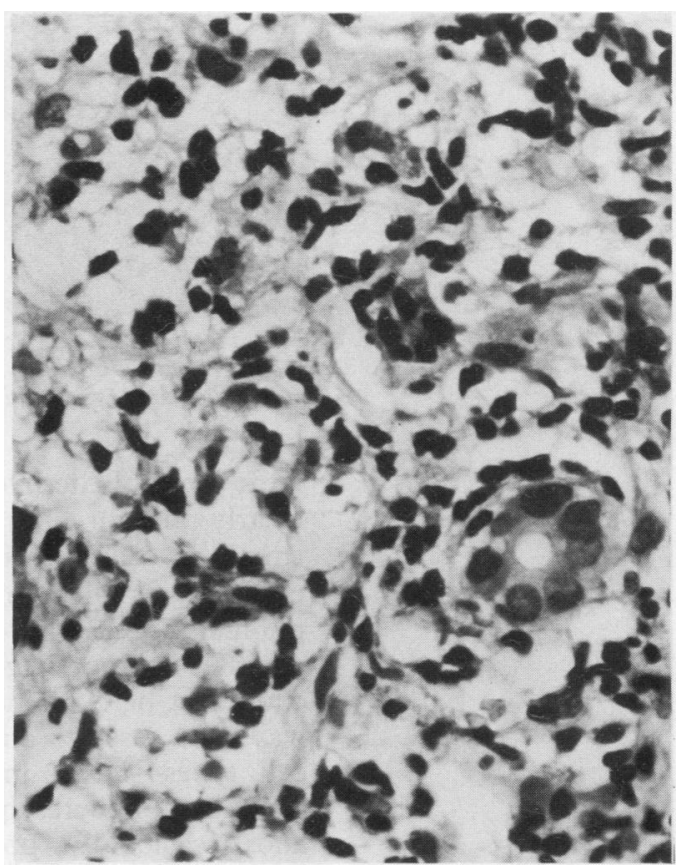

Figure 4 Case 4: tumour cells have dark, irregular nuclei, and little or no cytoplasm is visible (haematoxylin and eosin).

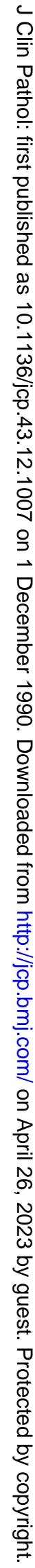




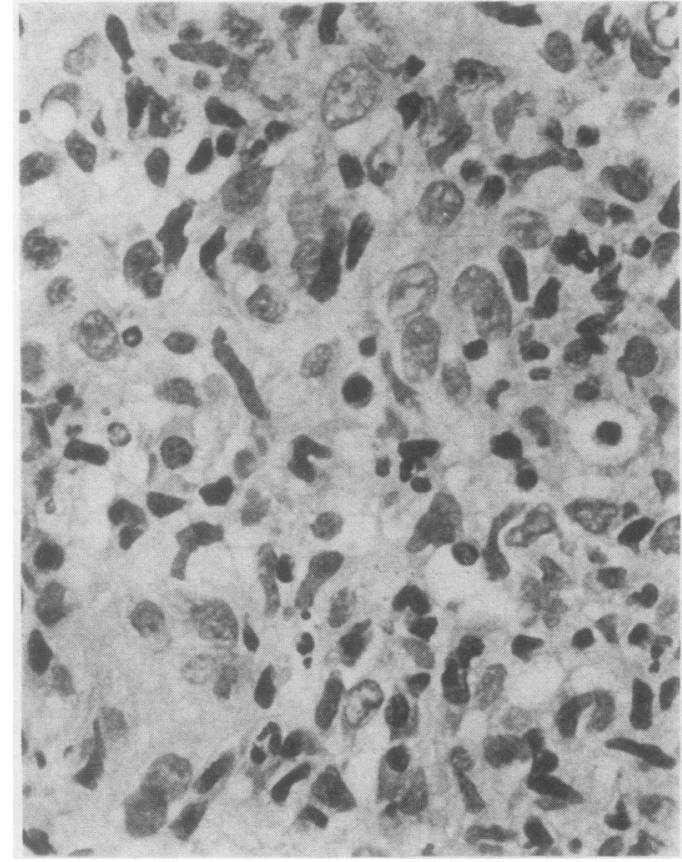

Figure 5 Case 6: mixture of several cell types-large, immature lymphoid cells, small lymphocytes, and polymorphs (mainly eosinophils); a few epithelioid cells are also present, one of which is multinucleate (bottom left) (haematoxylin and eosin).

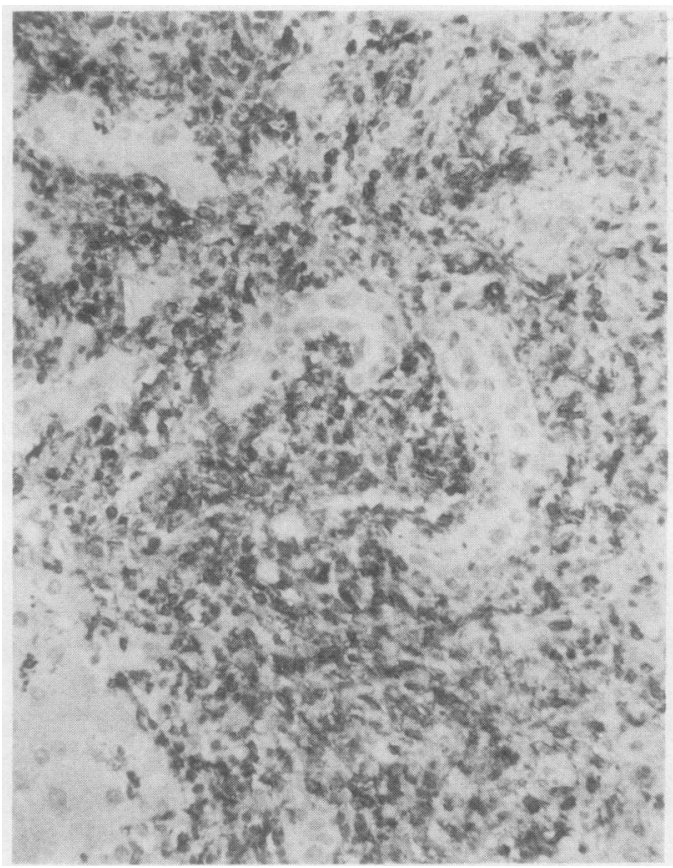

Figure 6 Case 6: many cells in the infiltrate stain positively with UCHL-1, a pan T-cell marker. Note intact bile ducts (streptavidin-biotin).

large areas of the liver parenchyma, and were clearly tumour-like. These also consisted of small $T$ cells; thus five cases in all were classified as pleomorphic small $T$ cell $1 y m-$ phomas. In cases 2, 4, and 7 extensive parenchymal haemorrhages were present which could not be explained as no vascular disease was seen. Cases 3 and 6 showed a mixture of cell types-large, immature lymphoid cells, small lymphocytes, plasma cells, eosinophils and occasionally, poorly formed granulomas (fig 5). Most lymphoid cells in both cases stained for $T$ cell markers (fig 6) and they were classified as $T$ zone lymphomas. Liver

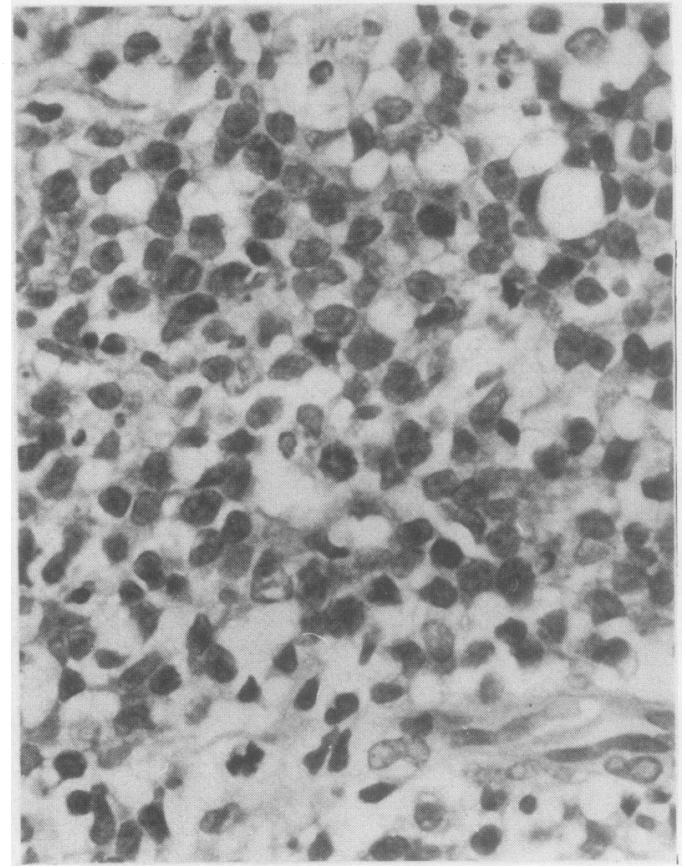

Figure 7 Case 10: uniform population of large lymphoid tumour cells with nuclei containing finely stippled chromatin (haematoxylin and eosin).

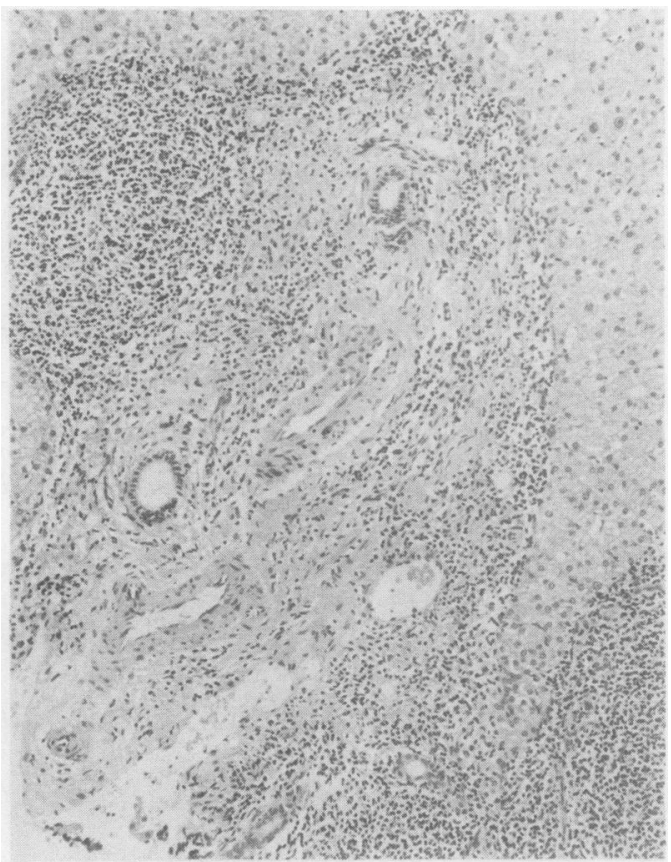

Figure 8 Case 1: well defined nodular lymphoid infiltrate (haematoxylin and eosin).

biopsy specimens in cases 5 and 10 and a resection specimen in case 10 showed tumour cell masses. These consisted of large cells with nuclei showing a finely stippled chromatin pattern and were regarded as lymphoblastic (fig 7). Both stained for $\mathrm{T}$ cell markers, albeit only moderately. Case 1 differed from the rest in that the microscopic infiltrate was well defined and nodular (fig 8) and consisted of small centrocytes (fig 9) which stained for B cell markers (fig 10), the only case in the series to do so.

Bile duct disease as a result of tumour invasion was not seen in any of the cases. 


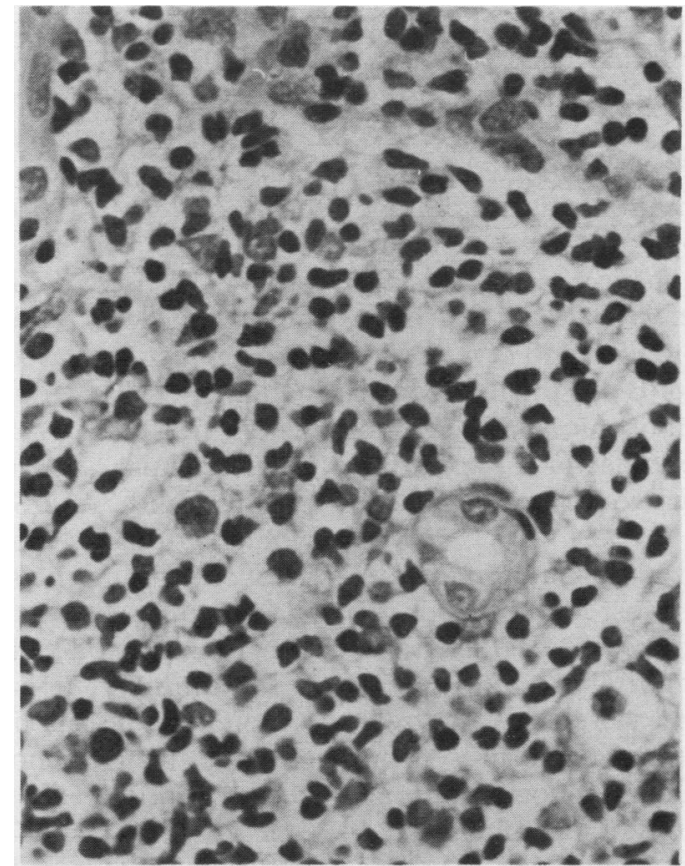

Figure 9 Case 1: tumour cells with small, dark, slightly irregular nuclei (haematoxylin and eosin).

\section{Discussion}

The 50 case reports that have appeared during the past decade showed a male to female preponderance of 4 to $1 .^{3-24}$ Primary lymphoma of the liver occurred over a wide age range: 7 to 78 years (mean $46 \cdot 6$ ). The main presenting features were pain $(n=30)$, hepatomegaly $(n$ $=29)$, and a palpable mass $(n=18)$. Other clinical manifestations included jaundice $(\mathrm{n}=$ 3 ), pleural effusion ( $\mathrm{n}=2$ ), and thrombocytopenia ( $n=1)$. Fever, night sweats, weight loss (" $B$ " symptoms) had been experienced by nearly half the patients ( $\mathrm{n}=$ 23). On investigation, most tumours were found to be solitary or multiple masses $(n=$ $42)$; the rest $(n=8)$ showed diffuse infiltration of the liver. In 25 cases where size was stated, this ranged from 4.0 to $18.0 \mathrm{~cm}$ (average 11.5 $\mathrm{cm}$ ). The tumour was confined to the right lobe in 19 cases, to the left in 10, and affected both in 21.

The histological appearances were described using a variety of terms, but 42 were regarded as "high grade" ("large cell", "histiocytic", "immunoblastic") 3-68-1315-23 and eight as "low grade" ("small cell", "lymphocytic," "centrocytic"), ${ }^{7914192024}$ diffuse, non-Hodgkin's lymphomas.

Immunocytochemistry was carried out in 11 cases. Seven were regarded as B cell ${ }^{51522}$ and four as $\mathrm{T}$ cell $^{717}$ in origin. Neither the morphological classification nor the phenotype related to prognosis which, however, was surprisingly good.

Twenty eight patients were alive and well at an average of 40.7 months, apparently free of disease, and most of them had probably been cured. Six were alive with disease at an average of 14.8 months and six had died of disease at an average of 13.5 months. A further eight patients died of other causes (septicaemia or haemorrhage, or both) while being investigated

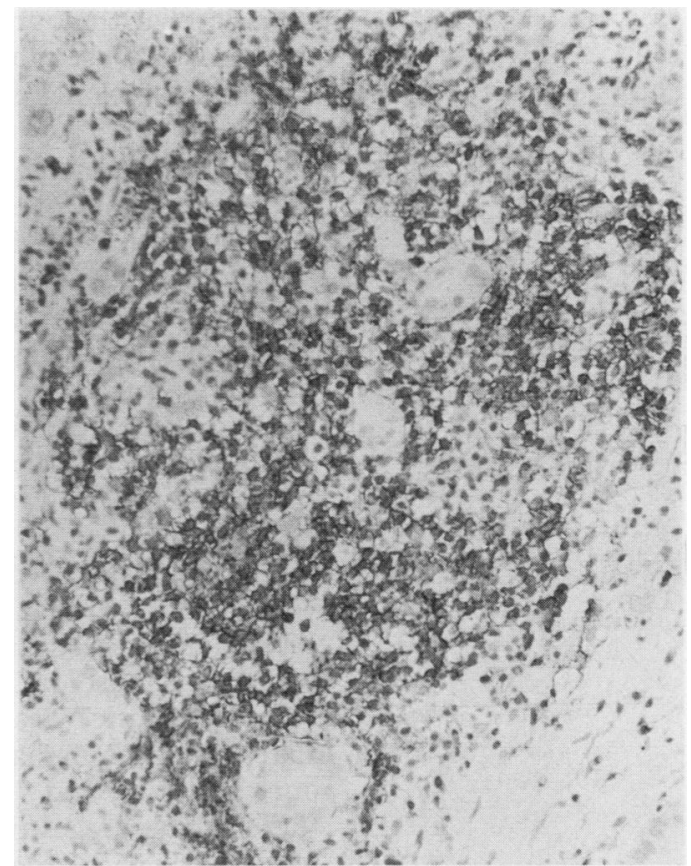

Figure 10 Case 1 : most cells stain with L26, a B cell marker. Again, note intact bile ducts (streptavidinbiotin.

or soon after treatment had began. Surgical resection was carried out in 14 cases, radiotherapy in six, and multiagent chemotherapy in 38. Patients who had surgery did best: all but one were disease free at an average of 47 months: most (12 of 14) had solitary tumours confined to one lobe of the liver. ${ }^{49_{11-131517-19}}$

The growing number of case reports of primary lymphoma of the liver indicates that this tumour may not be all that rare. The first important clue to the diagnosis arises from the clinical presentation which is usually pain in the right upper quadrant or the epigastrium and a palpable mass. The diagnosis is much more difficult, however, in the presence of diffuse hepatomegaly. " $B$ " symptoms - that is, fever, night sweats, and weight loss-should, however, direct the clinician towards the correct diagnosis. Nearly half of previously reported cases and eight of 10 in the present series had experienced these symptoms.

Laboratory investigations are not helpful, but varying degrees of abnormality in liver function tests, particularly raised activities of serum aminotransferases and alkaline phosphatase, have been frequently recorded. Imaging techniques are particularly useful in showing the extent of liver disease and the lack of lymph node, bone marrow, and other organ disease. The appearances of liver biopsy specimens may be unusual, and initial misdiagnoses, particularly of carcinoma, have been reported quite frequently. ${ }^{38101720}$ In this series chronic active hepatitis, "granulomatous cholangitis," and inflammatory pseudotumour were the referring diagnoses in five cases and anaplastic carcinoma in one. The most helpful diagnostic feature in a liver biopsy specimen is the destructiveness of the infiltrate, whatever its type, which rules out benign inflammatory conditions, whereas an appropriate range of immunocytochemistry excludes 
an epithelial tumour-that is, carcinoma-or inflammatory pseudotumour which invariably contains polyclonal plasma cells in large numbers.

All 50 primary lymphomas reported to date and the 10 cases presented in this study have been of diffuse non-Hodgkin's type. Descriptive morphological terms have varied according to the classification preferred, but most have been regarded as "high grade" and seven of 11 cases investigated were of B cell phenotype. In this series five were pleomorphic small cell, two $\mathrm{T}$ zone, and two lymphoblastic $\mathrm{T}$ cell lymphomas; only one was centrocytic and of B cell phenotype.

The three cases reported by Gaulard et al in young adults bear the most resemblance to cases in this series. ${ }^{7}$ Liver disease was described as diffuse, sinusoidal, or portal in all three, and "pseudopeliotic" lesions were seen in two. Extensive haemorrhages were also present in our cases 2, 4, and 7. This phenomenon may therefore be suggestive of a $\mathrm{T}$ cell phenotype, particularly with a pleomorphic small cell morphology. One further case of $\mathrm{T}$ cell lymphoma was reported on the basis of staining of tumour cells by a pan-T cell (UCHLI) antibody. ${ }^{17}$ Thus the present series is different from most others reported previously. As six patients had initially been misdiagnosed, this indicates a lack of awareness of this range in the spectrum of primary lymphomas of the liver. It is of further interest to note that a tumour with features of a "mucosa associated lymphoid tissue" lymphoma ("maltoma") is yet to be described at this site.

The clinical course of patients in this series seems poor at first sight when compared with those reported previously, especially in the larger series, ${ }^{3-9}$ but this impression may not be correct. To begin with, only one patient (case 1) had surgically resectable disease. Overall, this is the best prognostic indicator as shown by an analysis of reported cases. All 14 patients who had had a "curative" resection were alive at an average of 47 months and only one had residual disease. ${ }^{411-131517-19}$ Results may also improve with experience. Osborne et al treated 10 patients with multiagent chemotherapy of whom only two had a surgical resection. ${ }^{6}$ All patients were alive at an average of 2.4 years and six were in complete remission. Dement et al reported six cases treated by combined chemo-and radiotherapy, ${ }^{8}$ three of whom were alive and well at 12,28 , and 28 months. Ryan et al also obtained good results in a series of nine cases where multiagent chemotherapy was applied in addition to resection in four..$^{9}$

A closer examination of our case records shows that despite adversity-that is, diffuse, non-resectable tumours-they did not do too badly. Cases 3 and 9 are alive and well at three and six years; cases 1,2, and 4 survived for two years three months, one year three months, and one year six months, despite refusal of the diagnosis and delays in treatment in the latter two. Cases 6,7 , and 8 presented with severe associated diseases from which they died soon after admission; case 10 died of postoperative complications; only case 5 showed no response and died of disease at six months. All things considered, the record of primary lymphoma of the liver remains encouraging.

Few clues to aetiology have emerged so far. Dement et al noted a history of exposure to chemicals (petrol, propane, chromium) in four of six cases ${ }^{8}$; this has not been documented by others. Viruses or disturbed immunity figure in several case reports. Chronic hepatitis B virus infection has been documented in five patients, ${ }^{9182024}$ two of whom had chronic persistent hepatitis, ${ }^{918}$ and one had cirrhosis and hepatocellular carcinoma. ${ }^{20}$ Recently three patients with AIDS have been reported in whom primary lymphoma of the liver developed, ${ }^{22-24}$ and the suggestion has been made that it be regarded as a tumour associated with human immunodeficiency virus infection. ${ }^{24}$

In summary, it is suggested that primary lymphoma of the liver has a greater morphological and phenotypic variability than has been recorded so far. The appearances, especially in a needle biopsy specimen, may be difficult to interpret but recognition is important as the prognosis is favourable. The diagnosis should be actively sought in the appropriate clinical setting.

Our thanks are due to Drs A G Gibson, T Betteridge, J H F Smith, Y Sivathondan, M McKean and Professor $C$ Wittekind for kindly letting us use their material; to $\mathrm{Mr}$ B Moores and $\bar{F}$ Moshtael for expert photographic and technical assistance; and to Mrs G Marshall for the difficult tasks of word processing, referencing, and typing.

1 Jaffe ES. Malignant lymphomas: pathology of hepatic involvement. Semin Liver Dis 1987;7:257-68.

2 Anthony PP. Primary lymphoma of the liver: a more optimistic point of view. Hepatology 1989;9:165-7.

3 Leahy MF, Ibrahim EM, Worth AJ. Primary hepatic ymphoma: two case reports and a review of the literature. Med Paediatr Oncol 1982;10:575-81.

4 Fekete $F$, Molas $G$, Tossen $j-C$, Degutt $C$, Languille $O$, Potet F. Lymphome histiocytaire primitif du foie. Étude de deux cas et revue de la littérature. Gastroenterol Clin Biol 1983;7:785-91.

5 Miller ST, Wollner N, Meyers PA, Exelby P, Jereb B, Miller DR. Primary hepatic or hepatosplenic non-Hodgkin's lymphoma in children. Cancer 1983;52:2285-8.

6 Osborne BM, Butler JJ, Guarda LA. Primary lymphoma of the liver. Ten cases and review of the literature. Cancer 1985;56:2902-10

7 Gaulard P, Zafrani ES, Mavier P, et al. Peripheral T-cell lymphoma presenting as predominant liver disease: a report of three cases. Hepatology 1986;6:864-8.

8 Dement SH, Mann RB, Staal SP, Kuhajda FP, Boitnott JK. Primary lymphomas of the liver. Report of six cases and review of the literature. Am J Clin Pathol 1987;88:255-63.

9 Ryan J, Straus DJ, Lange C, et al. Primary lymphoma of the liver. Cancer 1988;61:370-5.

10 Strayer DS, Reppun TS, Levin M, Deschryver-Kecskemeti K. Primary lymphoma of the liver. Gastroenterology 1980;78:1571-6.

11 Daniel SJ, Attiyeh FF, Dire JJ, Pyun HJ, Carroll DS, Atia A. Primary lymphoma of the liver treated with extended left hepatic lobectomy. Cancer 1985;55:206-9.

12 Ryoo JW, Manaligod JR, Walker MJ. Primary lymphoma of the liver. J Clin Gastroenterol 1986;8:308-11.

13 Miyamoto Y, Izvo M, Ikeya T, et al. Right hepatic lobectomy for primary lymphoma. Jpn J Surg 1986;16:292-7.

14 Aghai E, Quitt M, Lurie M, et al. Primary hepatic lymphoma presenting as symptomatic immune throm bocytopenic purpura. Cancer 1987;60:2308-11.

15 Redondo C, Martin L, Cano AL, Cabellon P, Vazquez JM, Collantes J. Primary lymphoma of the liver treated with hepatic lobectomy and chemotherapy. Cancer 1987;60: $736-40$.

16 Czerniak A, Soreide O, Halnan K, Krausz T, Edwards WH, Blumgart LH. Primary non-Hodgkin's lymphoma of the liver. Eur J Surg Oncol 1987;13:251-5.

17 Andreola S, Audisio RA, Mazzaferro V, Doci R, Makowka L, Gennari L. Primary lymphoma of the liver showing immunohistochemical evidence of T-cell origin. Dig Dis Sci 1988;33:1632-6.

18 Mills AE. Undifferentiated primary hepatic non-Hodgkin's lymphoma in childhood. Am J Surg Pathol 1988;12:721-6.
Sondenaa K, Stadaas JO. Primary non-Hodgkin's lym-

19 Sondenaa K, Stadaas JO. Primary non-Hodgkin's lymphoma treated wit 
20 Talamo TS, Dekker A, Gurecki J, Singh G. Primary hepatic malignant lymphoma. Its occurrence in a patient with chronic active hepatitis, cirrhosis and hepatocellular carcinoma associated with hepatitis B viral infection. Cancer 1980;46:336-9.

21 Devars du Mayne JF, Barge J, Damade R, Gaudin B, Legmann $P$, Cerf $M$. Lymphome malin primitif du foie et cirrhose: une association inédite. Ann Med Interne 1987; 138:34-7.

22 Lopez-Guillermo A, Saperas E, Campo E, Bruix J, Fonseca E, Rodes ACJ. Linfoma hepático asociado a SIDA Gastroenterologia y Hepatologia 1987;10:453-5.

23 Caccamo D, Pervez NK, Marchevsky A. Primary lymphoma of the liver in the acquired immunodeficiency syndrome. Arch Pathol Lab Med 1986;110:553-5.
24 Lisker-Melman M, Pittaluga S, Pluda JM, et al. Primary lymphoma of the liver in a patient with acquired immune lymphoma of the liver in a patient with acquired immune deficiency syndrome and ch

25 Hall PA, D'Ardenne AJ, Stansfeld AG. Paraffin section immunohistochemistry. 1. Non-Hodgkin's lymphoma. Histopathology 1988;13:149-60.

26 Norton AJ, Isaacson PG. Lymphoma phenotyping in formalin-fixed and paraffin wax-embedded tissues. 1. Range of antibodies and staining patterns. Histopathology 1989 14:437-46.

27 Norton AJ, Isaacson PG. Lymphoma phenotyping in formalin-fixed and paraffin-wax embedded tissues. Profiles of reactivity in the various tumour types. Histopathology 1989;14:557-79.

\section{Eponyms in pathology ...}

BRUCE, Sir David (1855-1931) was a British microbiologist who was born in Melbourne, Australia. He returned to Scotland in 1860 and studied medicine at Edinburgh, qualifying in 1881. He entered the Royal Army Medical Corps (RAMC) in 1833 and was posted to Malta, where in 1887 he discovered the cause of Malta (or undulant) fever; the causative organism is now known as Brucella melitensis, the disease brucellosis. He held the post of assistant professor of pathology at the army medical school (AMS) in Netley, after which he was sent to South Africa in 1894 to investigate the cause of nagana, a native disease of horses and cattle. He identified the organism now called Trypanosoma brucei. Research in Uganda in 1903 led him to discover the tsetse fly as the vector of sleeping sickness in man. In 1899 he was elected an FRS and in 1908 he was knighted. In 1919 he retired from the army, having risen to the rank of major-general. $\mathrm{He}$ was heartbroken at the death of his wife, to whom he was devoted, and died during her funeral.
NOCARD, Edward Isidore-Etienne (1850-1903) was a French veterinarian who was born in Provins near Paris. He studied veterinary medicine at Alfort and later became professor of pathology and director of the veterinary school there. In $\mathbf{1 8 8 8}$ he described the actinomycete organisms which caused bovine farcy. The germ is now called Nocardia, and the disease Nocardiasis.

SERTOLI, Enrico (1842-1910) was born in Sondrio, Italy. He was professor of experimental physiology in Milan when he described the cells of the testicular epithelium in 1865. 